\title{
The dyke swarm of fractionated tourmaline-bearing leucogranite and its link to the Vydra Pluton (Moldanubian Batholith), Šumava Mts., Czech Republic
}

\author{
Žilný roj diferencovaného turmalinického leukogranitu \\ a jeho vztah k masivku Vydry (moldanubický pluton, Šumava)
}

\author{
(8 figs, 8 tabs) \\ VLADIMÍR ŽÁČEK ${ }^{1}$ - PETR SULOVSKÝ \\ ${ }^{1}$ Czech Geological Survey, P. O. BOX 85, Klárov 3, 11821 Praha 1, Czech Republic \\ 2 Masaryk University, Kotlářská 6, Brno, Czech Republic
}

\begin{abstract}
Dykes of tourmaline-bearing aplitic leucogranite form a swarm rimming the peraluminous, S-type granite of the Vydra Pluton (part of the Moldanubian Batholith) at a certain distance $(2-4 \mathrm{~km})$. The leucogranite dykes have not been recorded any closer or even in the pluton itself. The medium-grained, slightly cataclastic dykes are $\sim 20 \mathrm{~cm}$ to $\sim 5$ metres wide, and discordant to regional foliation of the country rocks. Leucogranite is composed of quartz + albite + potassium feldspar + muscovite \pm tourmaline \pm biotite (accessoric apatite and U-Y-P-rich zircon). The rock shows low concentrations of $\mathrm{Ti}, \mathrm{Ca}$, very low mg number, is peraluminous $(\mathrm{A} / \mathrm{CNK}=1.21-1.36)$ and has moderate $\mathrm{K}_{2} \mathrm{O} / \mathrm{Na} \mathrm{O}_{2} \mathrm{O}$ of 0.53-1.14. Most of $\mathrm{Ca}$ is combined with $\mathrm{P}$ to form late apatite, additional phosphorus is bound especially in potassium feldspar. The high concentration of phosphorus in potassium feldspar $\left(0.65-0.95 \mathrm{wt} . \% \mathrm{P}_{2} \mathrm{O}_{5}\right)$ is in a sharp contrast to the low concentration of $\mathrm{P}$ in albite ( $0.01-0.17$ wt. $\% \mathrm{P}_{2} \mathrm{O}_{5}$ ), and it is interpreted as a result of a late- / post-magmatic alteration. Compared to the Vydra Pluton granites, leucogranite is slightly richer in $\mathrm{SiO}_{2}, \mathrm{Na}_{2} \mathrm{O}$ and $\mathrm{Rb}(200-240 \mathrm{ppm})$ and strongly enriched in $\mathrm{Sn}(17-34 \mathrm{ppm})$ and $\mathrm{B}$ (abundant tourmaline). It is moderately to strongly depleted in $\mathrm{V}, \mathrm{Cr}, \mathrm{Ni}, \mathrm{Sr}$, Ba, and LREE ( $\Sigma \mathrm{REE} \sim 7-40 \mathrm{ppm})$. The $\mathrm{K} / \mathrm{Rb}$ ratio ranges from 88 to $133, \mathrm{Rb} / \mathrm{Sr}=2.3-10.2$. Leucogranite is also characterized by low concentration of Th (mostly $1.2-3 \mathrm{ppm}$ ) and a low Th/U ratio (typically below 0.4 ). The new monazite $\mathrm{U}-\mathrm{Th}$ dating confirms the Variscan age $(326.6 \pm 6.9 \mathrm{Ma})$ of metamorphism in the surrounding metamorphic rocks.
\end{abstract}

Key words: leucogranite; tourmaline; feldspar; phosphorus; chemical composition; monazite dating; Vydra Pluton; Moldanubian Batholith; Bohemian Massif

\section{Introduction}

The composite Moldanubian Batholith represents the largest Variscan granite complex in the Bohemian Massif. The granitic rocks have been recently studied by many authors (e.g., Liew et al. 1989, Vellmer - Wedepohl 1994, Finger et al. 1997, Klečka - Matějka 1996, Matějka - Janoušek 1998, Gerdes et al. 2003 and references in these works). The current paper discusses mineralogy and geochemistry of a leucogranite dyke swarm rimming eastern margin one of the smaller granite plutons. This pluton, belonging to the western branch of the Moldanubian Batholith, is known as the Vydra Pluton, after the local river. This name was introduced by J. Kunský in 1938.

Numerous dykes of aplitic leucogranite have been recorded in the proximity of the eastern margin of the Vydra Pluton during the detailed mapping of the map 1:25000 sheet 22-334 Kvilda (Figs 1-2, for details see Žáček 2005, Žáček et al. 2005). This program has been a part of the regional mapping conducted by the Czech Geological Survey.

The dykes intruded migmatites, less frequently other metamorphic rocks such as biotite orthogneiss, quartzrich gneiss and amphibolite. Leucogranite is a subordinate rock-type that forms less than $0.1 \%$ of the mapped area. However it is unusual in having anomalously low Th-concentrations (mostly 1.2-3 ppm) revealed by field gamma-spectrometric measurements. These are much lower than values displayed by the most common country rock - migmatite (10-17 ppm Th). The detailed study has shown that leucogranite is an evolved granitic rock with P-rich potassium feldspar, showing affinity to the marginal two-mica granite facies of the Vydra Pluton.

\section{Samples and analytical techniques}

The studied samples have been obtained in field seasons 2004-2005; all localities (listed in Appendix) are situated on the map 1:25 000 22-334 Kvilda (see Figs 1-2 and Žáček 2005, Žáček et al. 2005 for details). Three leucogranite samples (G21, G30, G66) and samples from the Vydra Pluton - two-mica granite $(19,45,46)$ and biotite granite (51) were analyzed for bulk chemistry (Tables 1, 2). Five samples (G21, G30, 19, 45, 51) were studied with electron microprobe (Tables 4-8); two (51, G30a) were used for electron microprobe monazite dating. Modal composition of the samples is given in Table 1. Additional 10 samples of the Vydra granite were observed in thin sections. The field measurements with gamma spectrometer GRM-260/B were performed at 36 localities of various granites throughout the mapped area (11 leucogranite, 8 two-mica granite, 17 biotite granite) along with additional measurements in other, mostly metamorphic rocks. Magnetic susceptibility was measured in the field using KT-5 kappameter (Table 3).

All whole-rock analyses were carried out in laboratories of the Czech Geological Survey in Prague. The wet 
chemical analyses were made by V. Janovská and J. Šikl. Trace elements were analyzed by M. Kopecká and I. Svobodová using RFA and FAAS (V, Co). The REE were analyzed by ICP (H. Kotoučová). Chondrite values used for normalization are from Boynton (1984).

Microprobe data were obtained with the Cameca SX-100 electron microprobe at the Masaryk University in Brno. Analytical conditions for rock-forming minerals were accelerating voltage $15 \mathrm{kV}$, probe current $10-20 \mathrm{nA}$, acquisition time 10-30 s. Standards: augite ( $\mathrm{Si}, \mathrm{Mg})$, orthoclase $(\mathrm{K})$, jadeite $(\mathrm{Na})$, chromite $(\mathrm{Cr})$, almandine $(\mathrm{Al})$, andradite $(\mathrm{Fe}, \mathrm{Ca})$, rhodonite $(\mathrm{Mn})$ and sintered $\mathrm{TiO}(\mathrm{Ti})$.

The electron microprobe dating of monazite was performed with the same device, equipped with large PET crystals. The analytical conditions were $15 \mathrm{kV}$ accelerating voltage and $80 \mathrm{nA}$ probe current. The U was measured on M $\beta$ line (acquisition time $120 \mathrm{~s}$, detection limit

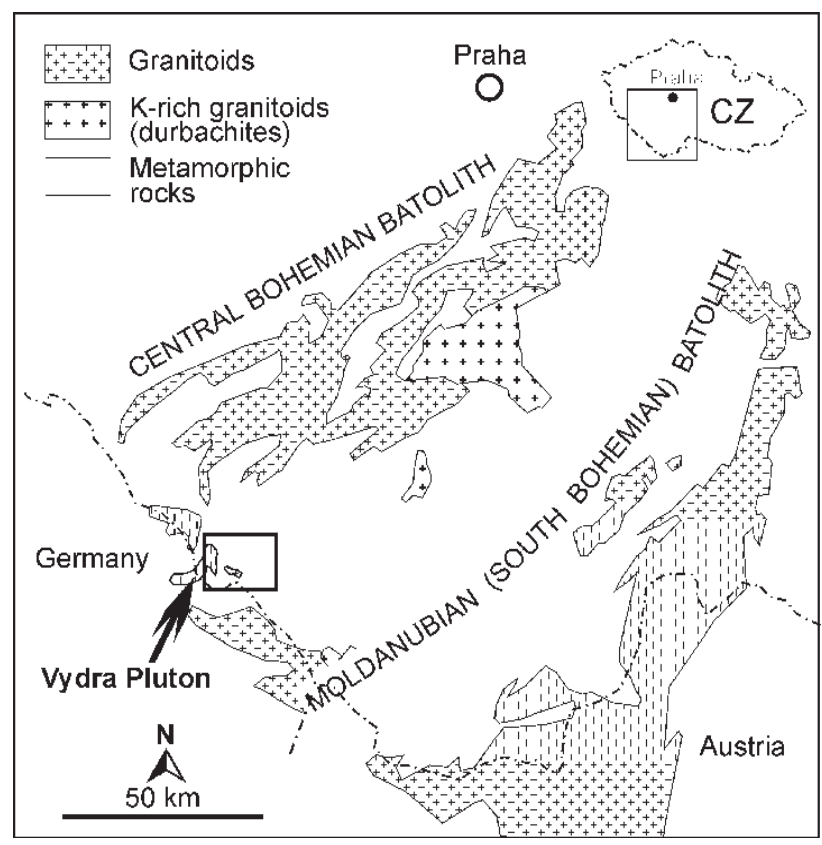

Fig. 1 The southern part of the Bohemian Massif situated between Prague and the state boundary, showing the main Variscan batholiths. Frame indicates the area studied and shown in Fig. 2.
$160 \mathrm{ppm}$ ), $\mathrm{Pb}$ on $\mathrm{M} \alpha$ line (acquisition time $300 \mathrm{~s}$, detection limit $90 \mathrm{ppm}$ ) and $\mathrm{Th}$ on Ma line (counting time $120 \mathrm{~s}$, detection limit $430 \mathrm{ppm}$ ). As standards were used synthetic $\mathrm{ThO}_{2}$, metallic $\mathrm{U}$ and vanadinite (BRGM) for $\mathrm{Pb}$. Further elements determined in monazite were measured on the following lines (in brackets are the relevant standards): $\mathrm{P} \mathrm{K} \alpha_{1}$ (apatite), $\mathrm{Si} \mathrm{K} \alpha_{1}, \mathrm{Al} \mathrm{K} \alpha_{1}$ (almandine), $\mathrm{La} \mathrm{L} \alpha_{1}\left(\mathrm{LaB}_{6}\right), \mathrm{Ce} \alpha_{1}\left(\mathrm{CeAl}_{2}\right), \operatorname{Pr} \mathrm{L} \beta_{1}\left(\mathrm{PrF}_{3}\right), \mathrm{Nd} \mathrm{L} \beta_{1}$ $\left(\mathrm{NdF}_{3}\right), \mathrm{Sm} \mathrm{L} \alpha_{1}\left(\mathrm{SmF}_{3}\right), \mathrm{Gd} \mathrm{L} \beta_{1}(\mathrm{GdF} 3)$, Dy L $\alpha_{1}$ $\left(\mathrm{DyP}_{5} \mathrm{O}_{14}\right), \mathrm{Y} \mathrm{L} \alpha_{1}(\mathrm{YAG})$ and $\mathrm{Ca} \mathrm{K} \alpha$ (andradite). Concentrations were corrected using the $\mathrm{ZAF}(\phi \rho \zeta)$ procedure of Pouchou - Pichoir (1984, 1985). The interferences of $\mathrm{Y} \mathrm{L} \gamma_{2,3}$ and $\mathrm{Th} \mathrm{M} \zeta_{1,2}$ on $\mathrm{Pb} \mathrm{M} \alpha$ peak and ThM $\gamma$ on $\mathrm{U} \mathrm{M} \beta$ were corrected through the procedure described by Åmli - Griffin (1975).

The chemical ages for individual measurements were calculated using the formula of Montel et al. (1993) with age errors derived from standard deviations of all three elements. From the individual age and associated error data, the inverse-variance weighted mean and $2 \mathrm{~s}$ error were calculated using Isoplot (Ludwig 2003). The regression line of the individual $\mathrm{Pb}$ vs. Th* values (concordia diagram) shows high degree of correlation $\left(\mathrm{R}^{2}>0.98\right)$ and a negligible intercept, confirming thus the validity of the dating (Cocherie et al. 1998). The measurements of age standards performed under the same conditions and employing identical data reduction procedures show good agreement with results of respected analysts (e.g. Finger, Jercinovic, Cocherie).

\section{Leucogranite dyke swarm}

The dyke swarm occupies a NW-SE trending zone at least $12 \mathrm{~km}$ long, extending between the village of Nové Hutě in the SE and Hut'ská Hora hill in the NW (Fig. 2). The dykes of leucogranite show general direction NW-SE, cutting Variscan metamorphic rocks, mainly migmatites (Fig. 3a). However, this area belongs to poorly exposed Sumava plains covered in places by extensive peat bogs. Even though the leucogranite is relatively resistant to weathering, the majority of the dykes were documented as blocks dispersed in this densely forested area. Since

Table 1 Estimated mineral abundances in analyzed samples (vol. \%), magnetic susceptibilities (MS) and results of field gamma-spectrometric measurements of $\mathrm{K}, \mathrm{U}$ and $\mathrm{Th}$.

\begin{tabular}{|c|c|c|c|c|c|c|c|c|c|c|c|c|}
\hline rock & Qtz & PI & Kfs & Bt & Ms & Tur & Chl & Accessory & MS $\left(10^{-3}\right)$ & K (\%) & $\mathrm{U}(\mathbf{p p m})$ & Th (ppm) \\
\hline \multicolumn{13}{|c|}{ leucogranite } \\
\hline G21 & 38 & 26 & 26 & $*$ & 10 & - & $*$ & Ap, Zrn & 0.05 & 3.4 & 5 & 1.7 \\
\hline G30 & 34 & 30 & 24 & 1 & 8 & 3 & - & Ap, Zrn & 0.04 & 3.3 & 5 & 4.1 \\
\hline G66 & 38 & 30 & 20 & - & 8 & 4 & - & Ap, Zrn, Mnz & 0.04 & 2.7 & 8 & 2.5 \\
\hline \multicolumn{13}{|c|}{ two-mica granite } \\
\hline 19 & 35 & 28 & 25 & 6 & 5 & - & 1 & $\mathrm{Ap}, \mathrm{Zrn}, \mathrm{Mz}$ & 0.05 & 4.2 & 9 & 12 \\
\hline 45 & 33 & 24 & 30 & 7 & 5 & - & 1 & Ap, Zrn, Ilm & 0.09 & 4.8 & 8 & 22 \\
\hline 46 & 35 & 25 & 30 & 5 & 5 & - & $*$ & Grt, Ap, Zrn, Mnz, Ilm & 0.05 & 3.3 & 7 & 7 \\
\hline \multicolumn{13}{|c|}{ porphyric biotite granite } \\
\hline 51 & 28 & 30 & 32 & 8 & 2 & - & - & Ap, Zrn, Xnt Mnz, Ilm, Ttn & 0.14 & 5.1 & 6 & 30 \\
\hline
\end{tabular}

* accessoric mineral 
Table 2 Chemical compositions of leucogranites and granites from the Vydra Pluton (major elements wt. \%, trace elements ppm).

\begin{tabular}{|c|c|c|c|c|c|c|c|}
\hline \multirow{2}{*}{$\begin{array}{l}\text { rock } \\
\text { sample }\end{array}$} & \multirow{2}{*}{\begin{tabular}{|c|}
$\begin{array}{c}\text { Bt gra- } \\
\text { nite }\end{array}$ \\
51
\end{tabular}} & \multicolumn{3}{|c|}{ two -mica granite } & \multicolumn{3}{|c|}{ leucogranite } \\
\hline & & 45 & 46 & 19 & G30 & G21 & G66 \\
\hline $\mathrm{SiO}_{2}$ & 68.90 & 72.46 & 73.28 & 73.80 & 72.37 & 74.86 & 75.24 \\
\hline $\mathrm{TiO}_{2}$ & 0.43 & 0.20 & 0.17 & 0.09 & 0.14 & 0.05 & 0.02 \\
\hline $\mathrm{Al}_{2} \mathrm{O}_{3}$ & 15.59 & 15.17 & 14.17 & 14.66 & 15.15 & 14.29 & 14.59 \\
\hline $\mathrm{Fe}_{2} \mathrm{O}_{3}$ & 0.75 & 0.50 & 0.84 & 0.51 & 0.41 & 0.32 & 0.51 \\
\hline $\mathrm{FeO}$ & 2.39 & 0.79 & 0.92 & 0.71 & 1.05 & 0.30 & 0.28 \\
\hline MgO & 0.82 & 0.38 & 0.29 & 0.22 & 0.35 & 0.10 & 0.08 \\
\hline MnO & 0.063 & 0.028 & $8 \quad 0.031$ & 0.061 & 0.046 & 0.025 & 0.035 \\
\hline $\mathrm{CaO}$ & 1.81 & 0.60 & 0.66 & 0.70 & 0.53 & 0.53 & 0.36 \\
\hline $\mathrm{BaO}$ & 0.209 & 0.024 & $4 \quad 0.028$ & 0.021 & 0.027 & $<0.005$ & $<0.005$ \\
\hline $\mathrm{Li}_{2} \mathrm{O}$ & 0.01 & 0.024 & $4 \quad 0.018$ & 0.028 & 0.03 & 0.006 & 0.004 \\
\hline $\mathrm{Na}_{2} \mathrm{O}$ & 2.75 & 3.01 & 2.95 & 3.53 & 4.31 & 3.78 & 4.47 \\
\hline $\mathbf{K}_{2} \mathbf{O}$ & 5.09 & 4.96 & 4.87 & 4.26 & 3.85 & 4.30 & 2.49 \\
\hline $\mathbf{P}_{2} \mathbf{O}_{5}$ & 0.24 & 0.308 & $\begin{array}{ll}8 & 0.087\end{array}$ & 0.169 & 0.272 & 0.24 & 0.372 \\
\hline $\mathbf{F}$ & 0.079 & 0.073 & 30.055 & 0.067 & 0.099 & 0.051 & 0.111 \\
\hline $\mathrm{H}_{2} \mathrm{O}^{+}$ & 0.94 & 0.99 & 0.96 & 0.87 & 0.96 & 0.75 & 0.93 \\
\hline $\mathrm{H}_{2} \mathrm{O}^{-}$ & 0.19 & 0.15 & 0.21 & 0.12 & 0.11 & 0.10 & 0.14 \\
\hline$-\mathrm{O}=\mathrm{F}$ & -0.033 & -0.031 & $1-0.023$ & -0.028 & -0.042 & -0.021 & -0.047 \\
\hline Total & 100.30 & 99.69 & 99.58 & 99.84 & 99.76 & 99.75 & 99.97 \\
\hline V & 21 & 12 & $<10$ & $<10$ & $<10$ & $<10$ & n.a. \\
\hline Co & 7 & $<5$ & $<5$ & 5 & 5 & $<5$ & n.a. \\
\hline $\mathrm{Cr}$ & 17 & 5 & 5 & 5 & 10 & 6 & 3 \\
\hline $\mathbf{N i}$ & 12 & 10 & 10 & 7 & 5 & 3 & 4 \\
\hline $\mathrm{Cu}$ & 10 & 6 & 6 & 6 & 6 & 43 & 8 \\
\hline Zn & 63 & 73 & 58 & 50 & 43 & 52 & 51 \\
\hline As & 5 & 6 & 5 & 3 & 6 & 4 & 33 \\
\hline $\mathbf{R b}$ & 183 & 305 & 241 & 291 & 240 & 200 & 234 \\
\hline $\mathrm{Sr}$ & 237 & 69 & 67 & 73 & 102 & 38 & 23 \\
\hline Y & 31 & 6 & 12 & 11 & 15 & 7.3 & 4 \\
\hline $\mathbf{Z r}$ & 302 & 92 & 112 & 56 & 37 & 12 & 22 \\
\hline Nb & 13 & 12 & 13 & 11 & 14 & 9 & 12 \\
\hline Mo & $<1$ & $<1$ & $<1$ & $<1$ & $<1$ & $<1$ & $<1$ \\
\hline Sn & $<2$ & 12 & 5 & 13 & 17 & 34 & 34 \\
\hline $\mathbf{P b}$ & 39 & 29 & 40 & 33 & 49 & 35 & 30 \\
\hline $\mathbf{U}$ & 4 & 13 & 6 & 9 & 2 & 4 & 9 \\
\hline La & 97.50 & 22.00 & 38.80 & 17.50 & 7.80 & 3.10 & 1.30 \\
\hline $\mathrm{Ce}$ & 187.90 & 49.20 & 81.20 & 36.60 & 14.30 & 6.00 & 2.60 \\
\hline $\operatorname{Pr}$ & 20.80 & 5.10 & 9.50 & 3.70 & 1.60 & 0.80 & $<0.70$ \\
\hline Nd & 76.60 & 21.60 & 34.30 & 14.90 & 5.70 & 2.20 & $<2.00$ \\
\hline Sm & 13.85 & 5.43 & 7.37 & 3.65 & 2.98 & 1.37 & $<0.30$ \\
\hline Eu & 1.77 & 0.41 & 0.53 & 0.35 & 0.61 & 0.33 & 0.17 \\
\hline Gd & 8.89 & 3.54 & 4.61 & 2.33 & 1.55 & 1.25 & 0.67 \\
\hline $\mathbf{T b}$ & $<0.70$ & $<0.70$ & $<0.70$ & $<0.70$ & $<0.70$ & $<0.70$ & $<0.70$ \\
\hline Dy & 6.01 & 1.90 & 2.62 & 2.29 & 2.25 & 1.20 & 0.70 \\
\hline Ho & 1.57 & $<0.50$ & 0.67 & 0.59 & $<0.50$ & 0.6 & $<0.50$ \\
\hline Er & 3.04 & 0.66 & 1.54 & 1.44 & 1.17 & 1.30 & 0.47 \\
\hline Tm & 0.36 & $<0.30$ & $<0.30$ & $<0.30$ & $<0.30$ & $<0.30$ & $<0.30$ \\
\hline $\mathbf{Y b}$ & 2.44 & 0.58 & 1.12 & 1.48 & 2.18 & 1.06 & 0.89 \\
\hline Lu & 0.38 & 0.10 & 0.18 & 0.23 & 0.35 & 0.17 & 0.15 \\
\hline tot REE & 421.00 & 111.00 & 182.00 & 85.00 & 40.00 & 19.00 & 7.00 \\
\hline A/CNK & 1.17 & 1.33 & 1.25 & 1.25 & 1.24 & 1.21 & 1.36 \\
\hline $\mathbf{A} / \mathbf{N K}$ & 1.55 & 1.47 & 1.40 & 1.41 & 1.35 & 1.31 & 1.45 \\
\hline $\mathrm{K}_{2} \mathrm{O} / \mathrm{Na}_{2} \mathrm{O}$ & 1.85 & 1.65 & 1.65 & 1.21 & 0.89 & 1.14 & 0.56 \\
\hline $\mathbf{K} / \mathbf{R b}$ & 231.00 & 135.00 & 168.00 & 122.00 & 133.00 & 178.00 & 88.00 \\
\hline $\mathbf{R b} / \mathbf{S r}$ & 0.77 & 4.42 & 3.60 & 3.99 & 2.35 & 5.26 & 10.17 \\
\hline f & 2.84 & 13.16 & 20.28 & 50.51 & 20.41 & 200.00 & 625.00 \\
\hline
\end{tabular}

$\mathrm{f}=1 /\left(\mathrm{MgO} \times \mathrm{TiO}_{2}\right)=$ "fractionation index" following Förster - Tischendorf (1994) the exposures are scarce, the distribution of dykes shown in Fig. 2 is only schematic.

Under the term "leucogranite dyke swarm" we understand a zone with abundant leucogranite dykes; isolated occurrences are known also outside this area. A larger $(12 \times 10 \mathrm{~m})$ leucogranite body in the vicinity of Zdíkov, in the NE part of the studied area, has been recently described by Škoda - Pálenský (2005). However the authors presented petrographic descriptions and concentrations for radioactive elements only. The rock characterized by the presence of tourmaline and a low Th concentration (below $2.1 \mathrm{ppm}$ ) corresponds well to the leucogranite suite described in the current paper.

The width of individual dykes is less than $10 \mathrm{~m}$, mostly ranging from $\sim 40 \mathrm{~cm}$ to several meters. The whole zone is 1 to $3 \mathrm{~km}$ wide; a significant swell (up to ca $5 \mathrm{~km}$ ) is apparent only in the area between the village of Horská Kvilda and Churán̆ov hill. As shown in Fig. 2, the leucogranite dyke swarm is rimming subsurface extension of the Vydra Pluton, as indicated by the Linsser density boundary at $-1000 \mathrm{~m}$ (following Šrámek in Žáček et al. 2005). However, the first leucogranite dykes appear at a certain distance, typically 3-4 km, from the edge of the pluton. They were not observed any closer or even within the pluton itself (Fig. 2).

Leucogranites have mostly aplitic appearance, are medium-grained, equigranular or slightly porphyritic. The potassium feldspar phenocrysts (where present) are up to $5 \mathrm{~mm}$ long. More or less pronounced cataclastic deformation is frequent (Fig. 3a). Leucogranites have very low magnetic susceptibility of $0.01-0.06 \times 10^{-3} \mathrm{SI}$, on average $0.03 \times 10^{-3} \mathrm{SI}$, and relatively low total radioactivity due to very low $\mathrm{Th}$ and moderate $\mathrm{U}$ contents.

The modal composition is simple with quartz and albite prevailing over potassium feldspar. The dykes are usually leucocratic and contain only small amount of micas, mostly muscovite only. Rarely, brown biotite slightly prevails over muscovite.

Potassium feldspar is rich in phosphorus (0.68-0.95 wt. $\% \mathrm{P}_{2} \mathrm{O}_{5}$ ) with $\mathrm{P}$ concentrations increasing towards the rim (see Table 4). Plagioclase is a pure albite, the concentration of $\mathrm{CaO}$ is mostly below 0.01 wt. $\%,(0.23$ wt. \% in one spot) and, compared to two-mica granite, it contains surprisingly low concentrations of phosphorus (0.0-0.17 wt. \% $\mathrm{P}_{2} \mathrm{O}_{5}$ ) further decreasing towards the rim (Tables 4, 5). Muscovite is poor in $\mathrm{TiO}_{2}(0.07-0.23 \mathrm{wt}$. $\%)$ and relatively rich in $\mathrm{Na}_{2} \mathrm{O}(0.43-0.65$ wt. \%) and $\mathrm{F}$ (0.32-0.66 wt. \%). Biotite (if present) is annite with low $\mathrm{mg}$ number $=\mathrm{Mg} /(\mathrm{Mg}+\mathrm{Fe})=0.14$, relatively poor in $\mathrm{TiO}_{2}(1.74-1.86$ wt. \%), and rich in $\mathrm{F}$ (ca 0.40 wt. \%) as well as $\mathrm{MnO}(0.4-0.9$ wt. \%).

Tourmaline, forming black prismatic crystals up to $5 \mathrm{~mm}$ long, is a typical mineral most of leucogranites and can appear in variable amounts up to 5 vol. \%. Tourmaline shows optical zoning with small bluish cores and wide brownish rims with many alternating darker and lighter coloured zones (Fig. 3b, c). Tourmaline is magnesian, X-site-vacant schorl with $\mathrm{Al}=6.58-6.81 \mathrm{apfu}$, 
Table 3 Radioactivity and magnetic susceptibility field measurements (map sheet 22-334 Kvilda).

\begin{tabular}{|l|cccccc|}
\hline & biotite granite & two-mica granite & leucogranite & migmatite* & Bt orthogneiss & amphibolite \\
\hline No of points & $\mathbf{2 1}$ & $\mathbf{1 2}$ & $\mathbf{1 2}$ & $\mathbf{2 1}$ & $\mathbf{9}$ & $\mathbf{3}$ \\
\hline K (wt. \%) & $3.4-6.3$ & $3.3-4.3$ & $2.3-4.3$ & $2.0-3.4$ & $3.3-4.5$ & $0.4-1.1$ \\
U (ppm) & $4-11$ & $5-12$ & $4-8$ & $3.1-5.9$ & $4.3-5.5$ & $1.1-1.9$ \\
Th (ppm) & $10-35$ & $7-15$ & $1.1-5.5$ & $10.3-17.4$ & $12.1-17.7$ & $0.7-2.5$ \\
Th/U & $2.0-5.9$ & $0.9-2.1$ & $0.2-0.9$ & $1.9-3.9$ & $1.5-5.5$ & $0.7-2.1$ \\
susceptibility $\left.\mathbf{( 1 0}^{-3} \mathbf{S I}\right)$ & $0.05-0.18$ & $0.03-0.10$ & $0.01-0.06$ & $0.09-0.46$ & $0.02-0.10$ & $0.48-49.00$ \\
\hline
\end{tabular}

* various types of migmatites and gneisses
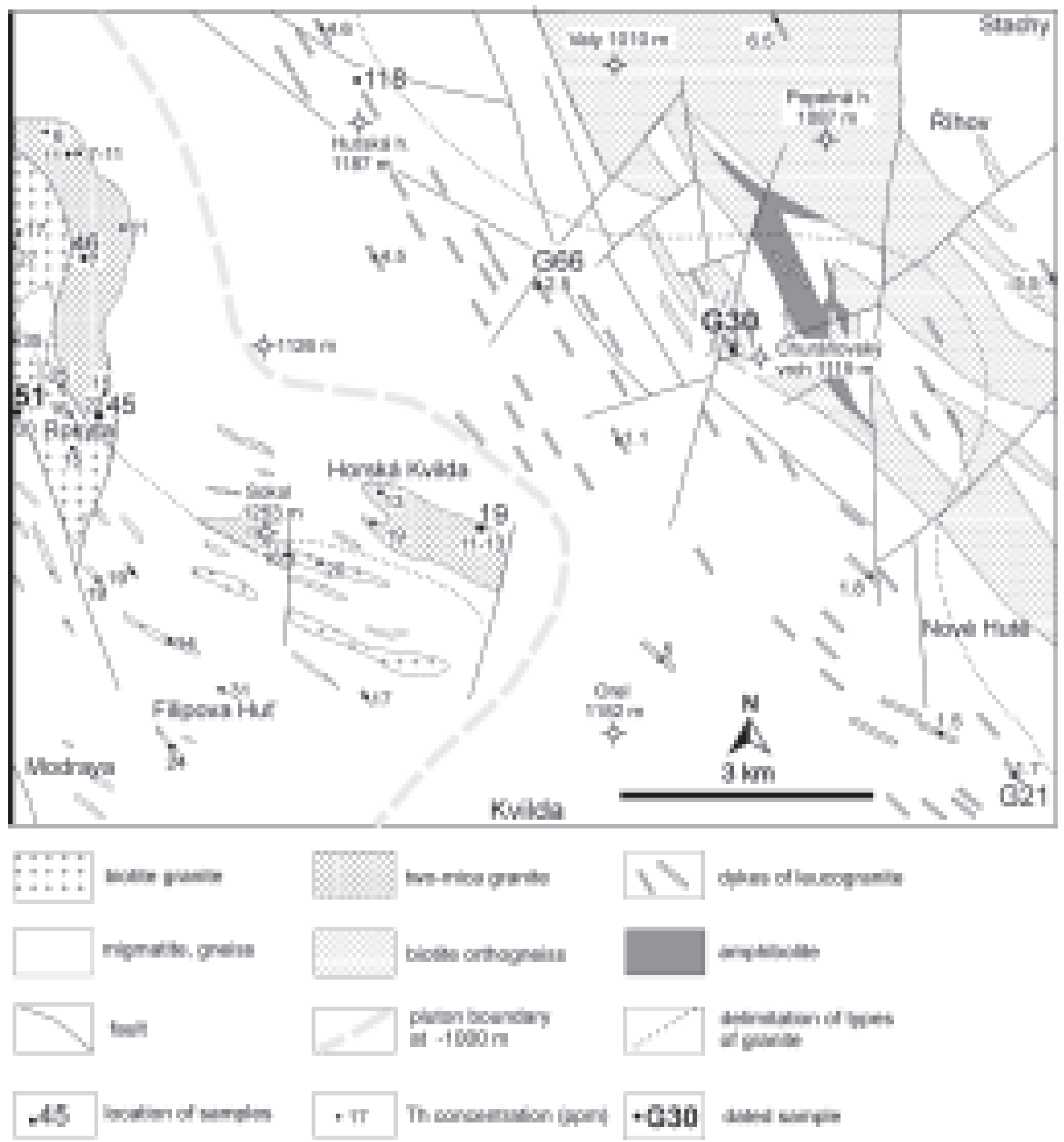

Fig. 2 Geological sketch of the leucogranite dyke swarm in the area of the 1:25 000 map sheet 22-224 Kvilda (after Žáček et al. 2005). Positions of samples and Th concentrations in granites are shown along with the main features of geology. The hidden part of the Vydra Pluton is indicated by Linsser indication of density boundary at $-1000 \mathrm{~m}$ (following data by J. Šrámek in Žáček et al. 2005). 

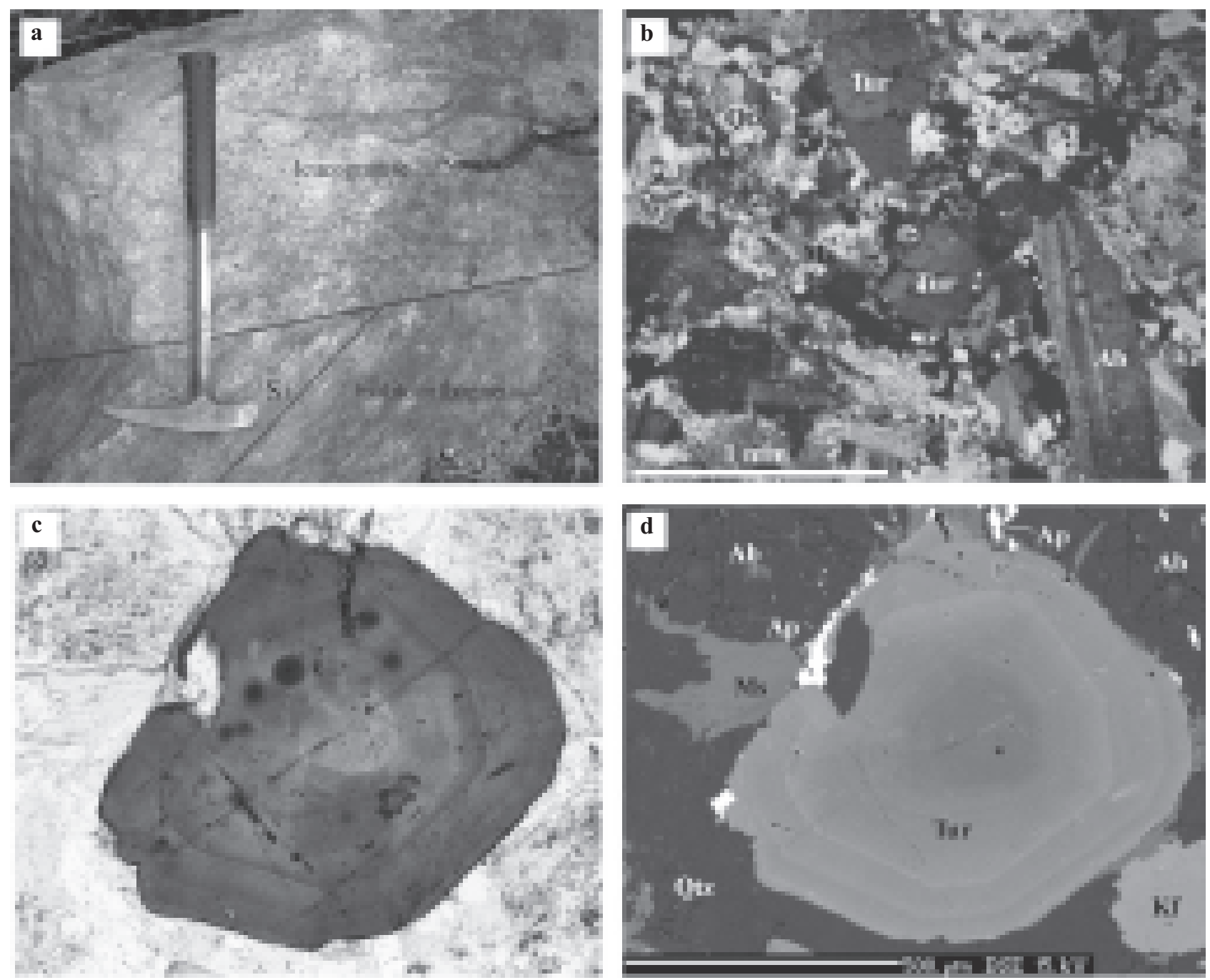

Fig. 3 a - Leucogranite dyke cutting (P-plane) the metamorphic foliation $\left(\mathrm{S}_{1}\right)$ of biotite orthogneiss. Churáňovský vrch, close to the sampling point G30; b - photomicrograph showing slightly cataclastic structure of leucogranite, sample G66. Abundant prismatic tourmaline phenocrysts occur along with muscovite, alkali feldspar and quartz. Crossed nicols, picture width $\sim 5 \mathrm{~mm} ; \mathrm{c}-$ zoned tourmaline crystal from the sample G30, with conspicuous halos rimming tiny inclusions of U-rich zircon (analysis in Table 8); $\mathrm{d}$ - The same picture in the BSE. Note anhedral apatite grains rimming tourmaline phenocryst.

$\mathrm{XMg}=\mathrm{Mg} /(\mathrm{Mg}+\mathrm{Fe})=0.15-0.43$, total X-site vacancy $29-50$ mol. \%, with $\mathrm{F}$ concentrations ranging between $0.09-0.59$ wt. $\%$, poor in $\mathrm{CaO}(0.0-0.17$ wt. $\%), \mathrm{TiO}_{2}$ $(0.0-0.50$ wt. \%), and $\mathrm{MnO}(0.07-0.23$ wt. \%) - see Fig. 4. Tourmaline crystals usually show a moderate compositional zoning. Typically $\mathrm{Ti}, \mathrm{F}, \mathrm{Na}$ and $\mathrm{Ca}$ abundances increase towards the rim, while $\mathrm{Al}, \mathrm{XMg}$ and $\mathrm{X}$-site vacancy decrease in the same direction. Tourmaline in quartz-tourmaline nodules in the wall-rock migmatite (sample 118 from Hut'ská Hora hill) shows a similar zoning pattern but its composition changes over wider range, from $\mathrm{Mg}$-Na-rich foitite to Ca-rich Fe-dravite. It is significantly richer in $\mathrm{Mg}, \mathrm{Ca}$ and $\mathrm{Ti}$, likewise the tourmaline from segregations in gneisses of the Kaplice Unit in southern Bohemia (Fig. 4, Table 7, see also Žáček - Vrána, 1999). Another abundant accessory mineral is apatite in the form of anhedral grains up to $0.5 \mathrm{~mm}$ long filling interstices and rimming other minerals (Fig. $3 \mathrm{c}, \mathrm{d}$ ), demonstrating its delayed/late crystallization. Very tiny U-P-Y-W-rich zircon grains, $\sim 3-5$ microns in diameter, occur mainly as inclusions in tourmaline phenocrysts and contain $\sim 6-7$ wt. $\% \mathrm{UO}_{2}, \mathrm{P}_{2} \mathrm{O}_{5}, \mathrm{Y}_{2} \mathrm{O}_{3}$ and 0.74 wt. $\%$ $\mathrm{WO}_{3}$, (Table 8). The inclusions of U-rich zircon in tourmaline are surrounded by conspicuous deep blue pleochroic haloes (Fig. 3c). Similar U, P, Y -rich zircons have

Table 4 Minor elements (wt. \%) detected in feldspars and garnet.

\begin{tabular}{|c|c|c|c|c|c|c|}
\hline & \multicolumn{4}{|c|}{ biotite granite two-mica granite } & \multirow{2}{*}{\multicolumn{2}{|c|}{$\begin{array}{c}\text { leucogranite } \\
\text { range }\end{array}$}} \\
\hline plagioclase & \multicolumn{2}{|c|}{ range } & \multicolumn{2}{|c|}{ range } & & \\
\hline An (mol. \%) & 21.00 & 22.00 & 5.00 & 10.00 & 0.00 & 1.00 \\
\hline $\mathrm{BaO}$ & $<0.01$ & $<0.01$ & $<0.01$ & & & \\
\hline SrO & $<0.01$ & 0.16 & $<0.01$ & $<0.01$ & & \\
\hline $\mathbf{P}_{2} \mathbf{O}_{5}$ & 0.07 & 0.12 & 0.22 & 1.00 & $<0.01$ & 0.17 \\
\hline K-feldspar & \multicolumn{2}{|c|}{ range } & \multicolumn{2}{|c|}{ range } & \multicolumn{2}{|c|}{ range } \\
\hline $\mathrm{Na}_{2} \mathrm{O}$ & 0.80 & 1.10 & 0.51 & 0.71 & 0.45 & 0.53 \\
\hline $\mathrm{BaO}$ & 0.37 & 0.57 & $<0.01$ & 0.10 & $<0.01$ & \\
\hline SrO & 0.01 & 0.06 & $<0.01$ & 0.10 & $<0.01$ & \\
\hline $\mathbf{P}_{2} \mathbf{O}_{5}$ & 0.03 & 0.09 & 0.20 & 0.50 & 0.65 & 0.95 \\
\hline garnet & \multicolumn{6}{|c|}{ range } \\
\hline $\mathbf{P}_{2} \mathrm{O}_{5}$ & & & 0.03 & 0.13 & & \\
\hline
\end{tabular}


Table 5 Chemical composition of feldspars.

\begin{tabular}{|c|c|c|c|c|c|c|c|c|c|c|c|c|}
\hline rock & \multicolumn{3}{|c|}{ biotite granite } & \multicolumn{3}{|c|}{ two-mica granite } & \multicolumn{6}{|c|}{ leucogranite } \\
\hline db & 51 & 51 & 19 & 19 & 19 & 46 & 4 & 16 & G30 & G30 & G66 & G66 \\
\hline mineral & PI & Kfs & $\mathbf{P I}$ & Pl & Kfs & $\mathbf{P l}$ & $\mathbf{K f}$ & fs & $\mathbf{P I}$ & Kfs & $\mathbf{P I}$ & Kfs \\
\hline $\mathrm{SiO}_{2}$ & 63.15 & 64.68 & 65.17 & 65.65 & 63.57 & 66.95 & 63.8 & & 68.82 & 64.09 & 67.91 & 63.94 \\
\hline $\mathrm{Al}_{2} \mathrm{O}_{3}$ & 23.29 & 18.57 & 21.81 & 21.06 & 19.16 & 20.87 & 18.7 & & 19.81 & 18.97 & 19.55 & 18.84 \\
\hline $\mathrm{FeO}^{\text {tot }}$ & n.d. & n.d. & 0.07 & n.d. & 0.11 & n.d & n.d & & n.d. & 0.06 & n.d. & n.d. \\
\hline MnO & 0.02 & 0.02 & 0.00 & 0.00 & 0.00 & 0.00 & 0.0 & & 0.00 & 0.00 & 0.00 & 0.00 \\
\hline $\mathrm{CaO}$ & 4.65 & 0.04 & 1.93 & 1.02 & 0.00 & 1.33 & 0.0 & & 0.23 & n.d. & n.d. & n.d. \\
\hline $\mathrm{Na}_{2} \mathrm{O}$ & 9.03 & 1.05 & 10.13 & 10.73 & 0.51 & 10.48 & 0.6 & & 11.33 & 0.49 & 11.48 & 0.45 \\
\hline $\mathrm{K}_{2} \mathrm{O}$ & 0.30 & 15.34 & 0.37 & 0.12 & 15.72 & 0.07 & 15.5 & & 0.09 & 15.80 & 0.09 & 16.03 \\
\hline $\mathrm{BaO}$ & 0.01 & 0.38 & n.d. & n.d. & n.d. & n.d & n.d & & n.d. & n.d. & n.d. & n.d. \\
\hline SrO & n.d. & 0.06 & n.d. & n.d. & n.d. & n.d. & n.d & & n.d. & n.d. & n.d. & n.d. \\
\hline $\mathbf{P}_{2} \mathbf{O}_{5}$ & 0.09 & 0.08 & 0.41 & 1.00 & 0.54 & 0.11 & 0.2 & & 0.06 & 0.95 & 0.17 & 0.68 \\
\hline total & 100.55 & 100.23 & 99.89 & 99.56 & 99.60 & 99.81 & 99.1 & 10 & 00.34 & 100.37 & 99.20 & 99.94 \\
\hline XAn & 0.218 & 0.002 & 0.093 & 0.049 & 0.000 & 0.065 & 0.003 & 0.011 & & & & \\
\hline XÁb & 0.765 & 0.093 & 0.886 & 0.944 & 0.047 & 0.930 & 0.060 & 0.984 & 0.04 & 0.99 & 0.041 & \\
\hline XKf & 0.017 & 0.896 & 0.021 & 0.007 & 0.953 & 0.004 & 0.937 & 0.005 & 0.95 & 0.01 & 0.959 & \\
\hline XCn & 0.000 & 0.007 & & & & & & & & & & \\
\hline XSr-Cn & 0.002 & & & & & & & & & & & \\
\hline
\end{tabular}

n.a $=$ not analyzed, n.d. $=$ not detected

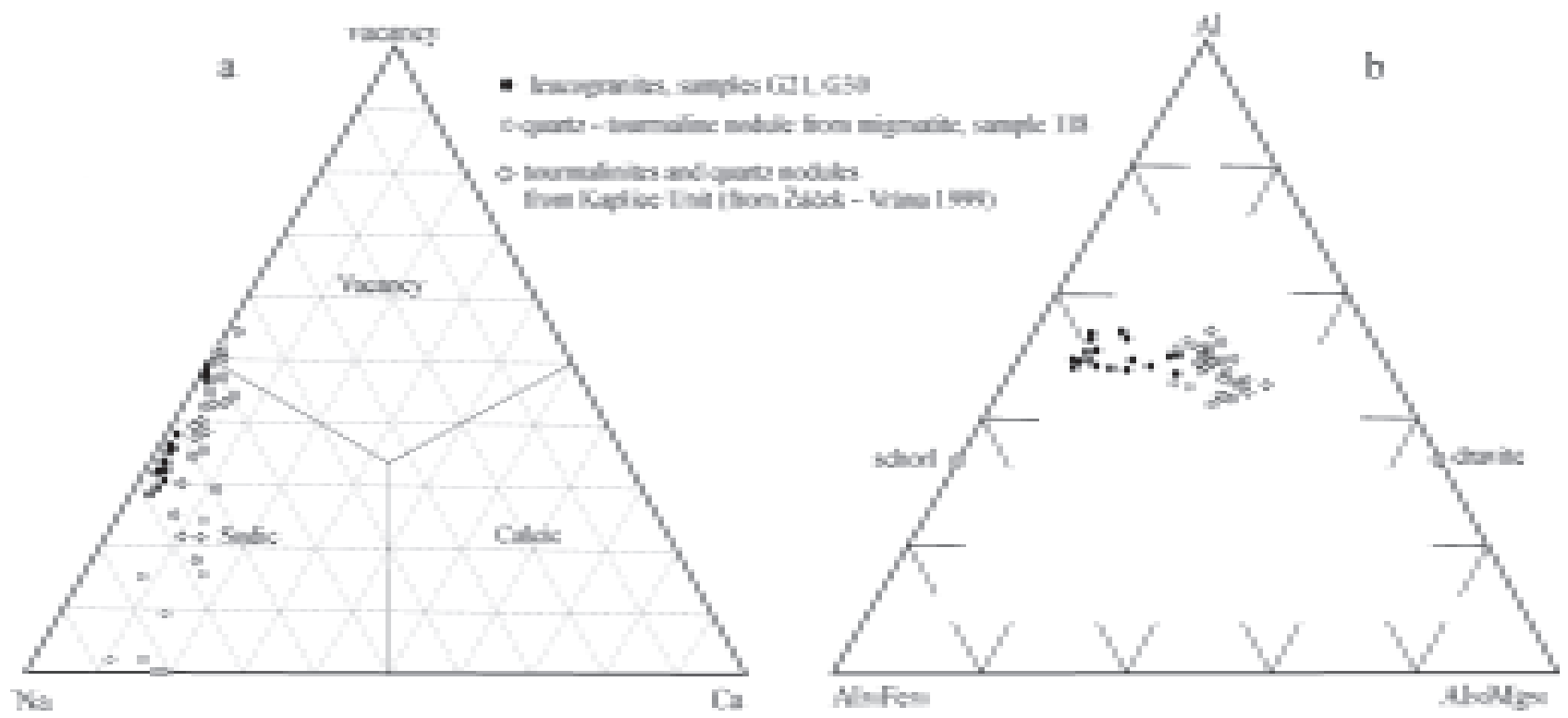

Fig. 4 a, b-Chemical composition of tourmaline from leucogranites in the diagram Na-Ca-vacancy (a) and Mg-Fe-Al (b).

been recently described by Breiter et al. (2005a) from fractionated Podlesí Granite (Krušné Hory Mts.).

\section{The Vydra Pluton}

The Vydra Pluton is a NNE-SSW (in the south W-E) trending granite body, approximately 12 by $3 \mathrm{~km}$. It is situated at the Czech - German border, c. $10 \mathrm{~km}$ south of Kašperské Hory in the Klatovy District, southern Bohemia. The pluton represents one of numerous granite bodies cropping out in the broader area of the Sumava Mts. - Böhmerwald. Most of the area belongs to the Monotonous part of the Moldanubian Zone (Jenček Vajner 1968, Dallmeyer et al. 1995) built, apart from granite bodies, by sillimanite - biotite \pm cordierite mig- matite and gneiss with minor orthogneisses, amphibolites, quartzites, and calc-silicate rocks. According to map of the total Bouguer anomalies with the Linsser indications of density boundaries (Šrámek in Žáček et al. 2005), the Vydra Pluton represents an apical part of a larger hidden granite body, as indicated by an extensive gravimetric low. The central part of the exposed pluton is formed by porphyritic biotite granite. Equigranular two-mica granite rims the eastern margin of the Vydra Pluton, forming a zone $1-2 \mathrm{~km}$ wide (including its hidden part). The contact was not observed in the field, but the two-mica granite most probably represents a marginal facies of the same granitic body.

Biotite granite is a medium- to coarse-grained, mostly porphyritic rock, in which prismatic feldspar phenocrysts 
Table 6 Chemical composition of micas, garnet and ilmenite.

\begin{tabular}{|c|c|c|c|c|c|c|c|c|c|c|c|c|}
\hline rock & \multicolumn{3}{|c|}{ biotite granite } & \multicolumn{6}{|c|}{ two-mica granite } & \multicolumn{3}{|c|}{ leucogranite } \\
\hline mineral & Bt & Ms & Ilm & Bt & Ms & Bt & Ms & Grt-c & Grt-r & Bt & Ms & Ms \\
\hline $\mathrm{TiO}_{2}$ & 3.06 & 0.44 & 53.29 & 3.10 & 0.73 & 2.21 & n.d. & n.d. & 0.03 & 1.86 & 0.23 & 0.07 \\
\hline $\mathrm{Cr}_{2} \mathrm{O}_{3}$ & 0.01 & 0.03 & n.d. & n.d. & n.d. & n.d. & n.d. & n.d. & n.d. & n.d. & n.d. & n.d. \\
\hline MnO & 0.29 & 0.02 & 4.80 & 0.29 & n.d. & 0.86 & n.d. & 6.65 & 11.77 & 0.49 & n.d. & n.d. \\
\hline MgO & 5.98 & 0.89 & n.d. & 5.96 & 0.66 & 4.24 & n.d. & 1.36 & 0.84 & 2.49 & 0.59 & 0.27 \\
\hline $\mathrm{CaO}$ & n.d. & n.d. & 0.02 & n.d. & n.d. & n.d. & n.d. & 0.36 & 0.46 & n.d. & n.d. & n.d. \\
\hline $\mathrm{Na}_{2} \mathrm{O}$ & 0.08 & 0.35 & n.a. & n.d. & 0.79 & n.d. & 0.42 & 0.03 & n.d. & n.d. & 0.65 & 0.52 \\
\hline $\mathbf{F}$ & 0.21 & 0.19 & n.a. & n.a. & n.a. & n.a. & n.a. & n.d. & n.d. & 0.41 & 0.36 & 0.66 \\
\hline$-\mathrm{O}=\mathrm{F}$ & -0.09 & -0.08 & -0.17 & -0.15 & -0.28 & & & & & & & \\
\hline SUM & 96.17 & 97.77 & 98.72 & 96.50 & 95.56 & 94.75 & 93.65 & 101.18 & 100.58 & 94.61 & 94.25 & 94.59 \\
\hline
\end{tabular}

n.a $=$ not analyzed, n.d. $=$ not detected

Table 7 Chemical composition of tourmaline of leucogranites and of quartz-tourmaline nodule from migmatite.

\begin{tabular}{|c|c|c|c|c|c|c|c|c|}
\hline sample & G66-c & G66 & G66-r & G30-c & G30-r & 118-c & 118 & $118-r$ \\
\hline $\mathrm{SiO}_{2}$ & 36.79 & 35.86 & 35.53 & 36.93 & 36.54 & 37.51 & 36.64 & 36.50 \\
\hline $\mathrm{TiO}_{2}$ & n.d. & 0.16 & 0.36 & 0.33 & 0.20 & 0.21 & 0.90 & 0.92 \\
\hline $\mathrm{Al}_{2} \mathrm{O}_{3}$ & 34.98 & 33.63 & 33.13 & 34.65 & 34.19 & 35.22 & 33.18 & 33.05 \\
\hline $\mathrm{FeO}^{\text {tot }}$ & 11.12 & 13.22 & 13.77 & 9.44 & 12.50 & 8.54 & 8.11 & 8.50 \\
\hline MnO & 0.12 & 0.22 & 0.20 & 0.07 & 0.16 & 0.09 & 0.08 & n.d. \\
\hline MgO & 2.25 & 1.66 & 1.39 & 3.93 & 1.87 & 4.13 & 5.35 & 5.57 \\
\hline $\mathrm{CaO}$ & n.d & 0.07 & 0.06 & 0.14 & 0.06 & n.d. & 0.44 & 0.79 \\
\hline $\mathrm{Na}_{2} \mathrm{O}$ & 1.61 & 2.00 & 1.81 & 2.02 & 1.59 & 1.52 & 2.07 & 1.87 \\
\hline $\mathbf{K}_{2} \mathbf{O}$ & n.d. & 0.06 & 0.05 & 0.04 & 0.04 & n.d. & n.d. & 0.04 \\
\hline $\mathbf{F}$ & 0.09 & 0.47 & 0.55 & 0.30 & 0.39 & n.d. & 0.35 & 0.46 \\
\hline$-\mathrm{O}=\mathrm{F}$ & -0.04 & -0.20 & -0.23 & -0.13 & -0.16 & -0.15 & -0.19 & \\
\hline total & 86.92 & 87.14 & 86.61 & 87.72 & 87.36 & 87.23 & 86.97 & 87.50 \\
\hline $\mathbf{S i}$ & 6.080 & 6.021 & 6.016 & 6.033 & 6.066 & 6.079 & 6.023 & 5.981 \\
\hline $\mathbf{T i}$ & 0.000 & 0.020 & 0.046 & 0.040 & 0.025 & 0.026 & 0.111 & 0.113 \\
\hline Al & 6.813 & 6.656 & 6.610 & 6.671 & 6.690 & 6.726 & 6.429 & 6.382 \\
\hline $\mathrm{Fe}^{2+}$ & 1.537 & 1.856 & 1.949 & 1.290 & 1.735 & 1.157 & 1.115 & 1.165 \\
\hline Mn & 0.017 & 0.031 & 0.029 & 0.010 & 0.022 & 0.013 & 0.011 & 0.000 \\
\hline Mg & 0.553 & 0.416 & 0.351 & 0.956 & 0.462 & 0.999 & 1.311 & 1.359 \\
\hline total Y & 15.000 & 15.000 & 15.000 & 15.000 & 15.000 & 15.000 & 15.000 & 15.000 \\
\hline $\mathbf{C a}$ & 0.000 & 0.013 & 0.011 & 0.025 & 0.010 & 0.000 & 0.103 & 0.191 \\
\hline $\mathbf{N a}$ & 0.516 & 0.652 & 0.593 & 0.640 & 0.512 & 0.486 & 0.873 & 0.815 \\
\hline $\mathbf{K}$ & 0.000 & 0.013 & 0.011 & 0.009 & 0.008 & 0.000 & 0.000 & 0.013 \\
\hline X-vacancy & 0.484 & 0.323 & 0.384 & 0.327 & 0.470 & 0.514 & 0.025 & 0.000 \\
\hline total $\mathrm{X}$ & 1.000 & 1.000 & 1.000 & 1.000 & 1.000 & 1.000 & 1.000 & 1.019 \\
\hline $\mathbf{F}$ & 0.049 & 0.247 & 0.293 & 0.155 & 0.202 & 0.000 & 0.181 & 0.236 \\
\hline Xmg & 0.265 & 0.183 & 0.153 & 0.426 & 0.210 & 0.463 & 0.540 & 0.539 \\
\hline
\end{tabular}

n.d. $=$ not detected

(5-20 mm long) represent 20-30 vol \%. The rock contains 20-30 vol. \% quartz, 20-35 vol. \% of plagioclase $\left(\mathrm{An}_{21-22}\right)$ and 30-40 vol. \% of potassium feldspar (microcline). The amount of brown biotite ranges between 7 and 12 vol. \%. Muscovite mostly reaches up to 2 vol. \% (Table 1). Chloritization of biotite is scarce. In one thin section from isolated granite intrusion at Horní Otýgl, SE of Mt. Sokol, about 5 vol. \% of cordierite was present.
Xenotime (crystals up to 250 microns), apatite and zircon are abundant accessory minerals; titanite, monazite and ilmenite are scarce.

Potassium feldspar is enriched in $\mathrm{BaO}(0.37-0.57$ wt. $\%)$ and $\mathrm{SrO}(0.03-0.09 \mathrm{wt} . \%)$, the concentration of $\mathrm{P}_{2} \mathrm{O}_{5}$ is low (0.03-0.09 wt. \%). The concentration of $\mathrm{P}_{2} \mathrm{O}_{5}$ in plagioclase corresponds to 0.07.0.12 wt. \% (see Table 4). Biotite is annite with $m g$ number $\sim 0.3$, the 
highest among the granite samples studied. It is rich in TiO 2 (2.9-3.1 wt. \%) and poor in $\mathrm{MnO}(\sim 0.3$ wt. \%) as well as F (0.13-0.21 wt. \%). Muscovite contains 0.41.0 wt. $\% \mathrm{TiO}_{2}, 0.28-0.35$ wt. $\% \mathrm{BaO}$ and $0.12-0.19$ wt. \% F. Scarce and tiny ilmenite contains 4.5 wt. \% $\mathrm{MnO}$ and 0.24 wt. $\% \mathrm{BaO}$. The mineral chemistry is presented in Tables 4-6.

Two-mica granite is an equigranular medium-grained, locally slightly cataclastic rock. It consists of roughly equal quantities of quartz, potassium feldspar, and plagioclase $\left(\mathrm{An}_{5-10}\right)$ with a weak normal compositional zoning. Both plagioclase and potassium feldspar are enriched in phosphorus $\left(0.2-1.0\right.$ and $0.2-0.5$ wt. $\%$ of $\mathrm{P}_{2} \mathrm{O}_{5}$, respectively), and poor in $\mathrm{BaO}$ and $\mathrm{SrO}$ (Table 4). Muscovite content varies between $6-10$ vol. $\%$ and this mineral usually slightly prevails over brown biotite (2-7 vol. \%). Biotite is annite with $m g$ number $0.2-0.3$, enriched in $\mathrm{TiO}_{2}(2.2-3.1$ wt. \%) and $\mathrm{MnO}(0.3-0.9$ wt. \%), poor in $\mathrm{Na}_{2} \mathrm{O}$ (below 0.01 wt. \%). Chloritization is scarce. Muscovite contains $0.4-0.8$ wt. $\% \mathrm{Na}_{2} \mathrm{O}$ and $0.5-0.8$ wt. $\%$ $\mathrm{TiO}_{2}$ (Tables 5, 6).

Rarely, cordierite, garnet and sillimanite occur in small quantities. Apatite and zircon are abundant accessory minerals; ilmenite, monazite and allanite are rare.

Garnet occurring in sample 46 as a cluster of euhedral crystals $0.3 \mathrm{~mm}$ across, is Mn-rich almandine (63-78 Alm, 15-33 Sps, 2-5 Prp, 1-2 Grs, mol. \%), enriched in phosphorus $\left(0.03-0.13\right.$ wt. $\left.\% \mathrm{P}_{2} \mathrm{O}_{5}\right)$ - see Table 6 .

\section{Chemical composition}

Leucogranites contain 72.4-75.2 wt. \% $\mathrm{SiO}_{2}, 14.3-15.2$ $\mathrm{Al}_{2} \mathrm{O}_{3}, 0.08-0.35 \mathrm{MgO}, 0.36-0.53 \mathrm{CaO}, 3.8-4.5 \mathrm{Na}_{2} \mathrm{O}$ and 2.5-4.3 $\mathrm{K}_{2} \mathrm{O}$ (Table 2). They show low concentrations of $\mathrm{TiO}_{2}(0.02-0.14$ wt. \%), low mg number, are peraluminous with $\mathrm{A} / \mathrm{CNK}=1.21-1.36$ and have moderate $\mathrm{K}_{2} \mathrm{O} / \mathrm{Na}_{2} \mathrm{O}$ of $0.53-1.14$. Majority of $\mathrm{Ca}$ is combined with $\mathrm{P}$ to form apatite. Excess phosphorus is bound mostly in potassium feldspar; as noted above, the plagioclase plays a little role in the total phosphorus budget.

Leucogranite is slightly enriched in $\mathrm{SiO}_{2}, \mathrm{Na}_{2} \mathrm{O}$ and $\mathrm{Rb}$ (200-240 ppm) and strongly enriched in Sn (17-34 ppm) and B (abundant tourmaline), compared to both facies of the Vydra Pluton. On the other hand, it is moderately to

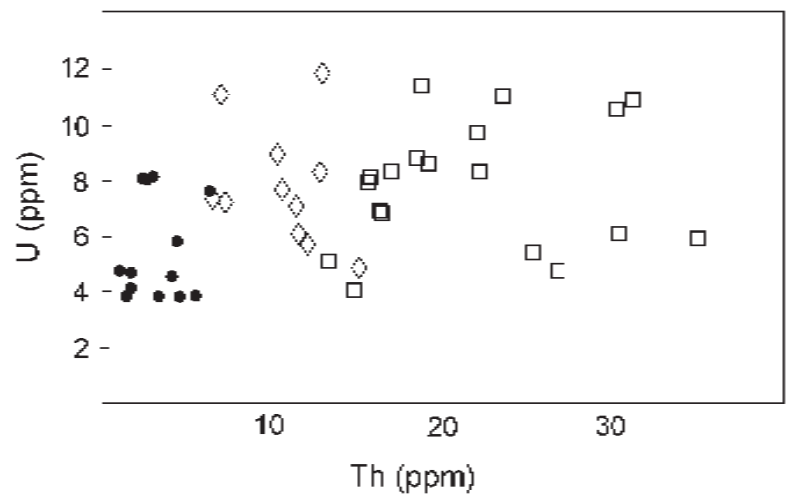

strongly depleted in $\mathrm{V}, \mathrm{Cr}, \mathrm{Ni}, \mathrm{Sr}, \mathrm{Ba}, \mathrm{Y}$, and $\mathrm{Eu}$, as well as the total $\operatorname{REE}(\sim 7-40 \mathrm{ppm})$. The leucogranites are poorer in LREE and relatively enriched in HREE compared to the Vydra Pluton granites (Fig. 7). The concentrations of $\mathrm{U}$ are $2-8 \mathrm{ppm}, \mathrm{Th}=1.1-6.5 \mathrm{ppm}$ (typically $1.2-3 \mathrm{ppm})$; the $\mathrm{Th} / \mathrm{U}$ ratio ranges between $0.2-1.4$, but mostly is below 0.4 (Fig. 5).

The "fractionation index" $\mathrm{F}=1 /\left(\mathrm{MgO} \times \mathrm{TiO}_{2}\right)$ following Förster - Tischendorf (1994) is for the three analyzed samples 20, 200 and 625. For comparison, the two-mica granite has $\mathrm{F}=13,20,51$, and the biotite granite $\mathrm{F}=$ 2.8. The $\mathrm{K} / \mathrm{Rb}$ ratio ranges from 88 to $133, \mathrm{Rb} / \mathrm{Sr}=2.3-$ $10.2, \mathrm{La}_{\mathrm{n}} / \mathrm{Sm}_{\mathrm{n}}=1.42-1.65$. The Harker plots and binary diagrams of selected trace elements vs. $\mathrm{SiO}_{2}$ show high negative correlations of silica with $\mathrm{Ti}, \mathrm{Fe}, \mathrm{Al}, \mathrm{Mg}, \mathrm{Ca}$, $\mathrm{Sr}, \mathrm{Y}$ and $\mathrm{Zr}$ and positive correlations with $\mathrm{Na}, \mathrm{Sn}$ and A/CNK (Fig. 6).

Vydra Pluton. In the $\mathrm{R}_{1}-\mathrm{R}_{2}$ plot of De La Roche et al. (1980) (not shown) the two-mica granite corresponds to granite, the sample of biotite granite lies at the boundary between granite and granodiorite. Both rock types are peraluminous, highly potassic, (see Table 2).

Two-mica granite has $\mathrm{A} / \mathrm{CNK}=1.25-1.33$, the ratio $\mathrm{K}_{2} \mathrm{O} / \mathrm{Na}_{2} \mathrm{O}=1.21-1.65$ is higher than in leucogranites and lower than in biotite granite. The concentrations of Sn are elevated (5-13 ppm), concentrations of total REE vary between 82 and $182 \mathrm{ppm}$. The concentrations of $\mathrm{U}$ are 5-13 ppm, Th $=6.5-22 \mathrm{ppm}$ (mostly 7-13 ppm); the $\mathrm{Th} / \mathrm{U}$ ratios range between 0.6 and 3.1 but mostly are below 2.0 (Fig. 5); $\mathrm{Rb} / \mathrm{Sr}=3.6-4.4, \mathrm{La}_{\mathrm{N}} / \mathrm{Sm}_{\mathrm{N}}=2.6-3.3$, $\mathrm{Eu} / \mathrm{Eu}^{*}=0.3$.

Biotite granite has $\mathrm{A} / \mathrm{CNK}=1.17$, the $\mathrm{K}_{2} \mathrm{O} / \mathrm{Na}_{2} \mathrm{O}=$ 1.85. The concentration of $\mathrm{Sn}$ is very low (below $2 \mathrm{ppm}$ ), but other trace elements are higher than both in leucogranite and two-mica granite, the total REE concentration is $421 \mathrm{ppm}$. The concentrations of $U$ are 4 to $11 \mathrm{ppm}$, and $\mathrm{Th} 14$ to $31 \mathrm{ppm}$; the $\mathrm{Th} / \mathrm{U}$ ratio ranges between 1.6 and 5.9, but mainly between 2 and 5 (Fig. 5); $\mathrm{La}_{\mathrm{N}} / \mathrm{Sm}_{\mathrm{N}}=$ $4.4, \mathrm{Eu} / \mathrm{Eu}^{*}=0.5$.

\section{Monazite dating}

Leucogranites have not been dated due to lack of monazite but two new U-Th-Pb monazite electron microprobe

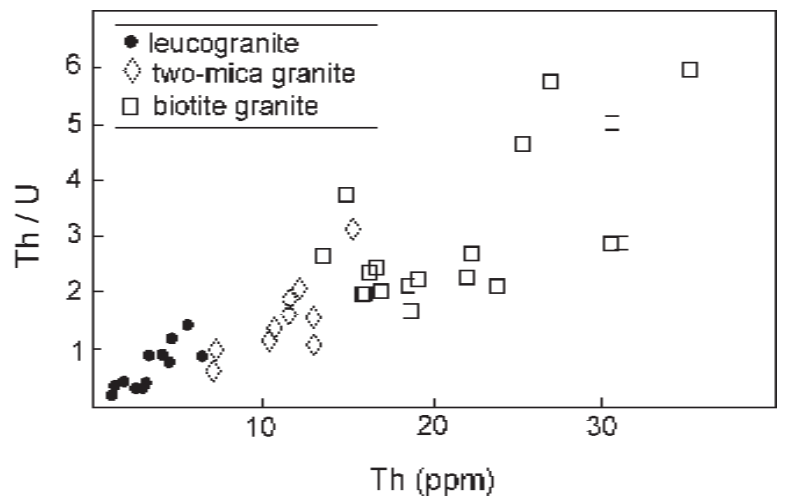

Fig. 5 a, b - Th versus $U$ and Th versus Th/U for leucogranite and two-mica granite and biotite granite of the Vydra Pluton. 

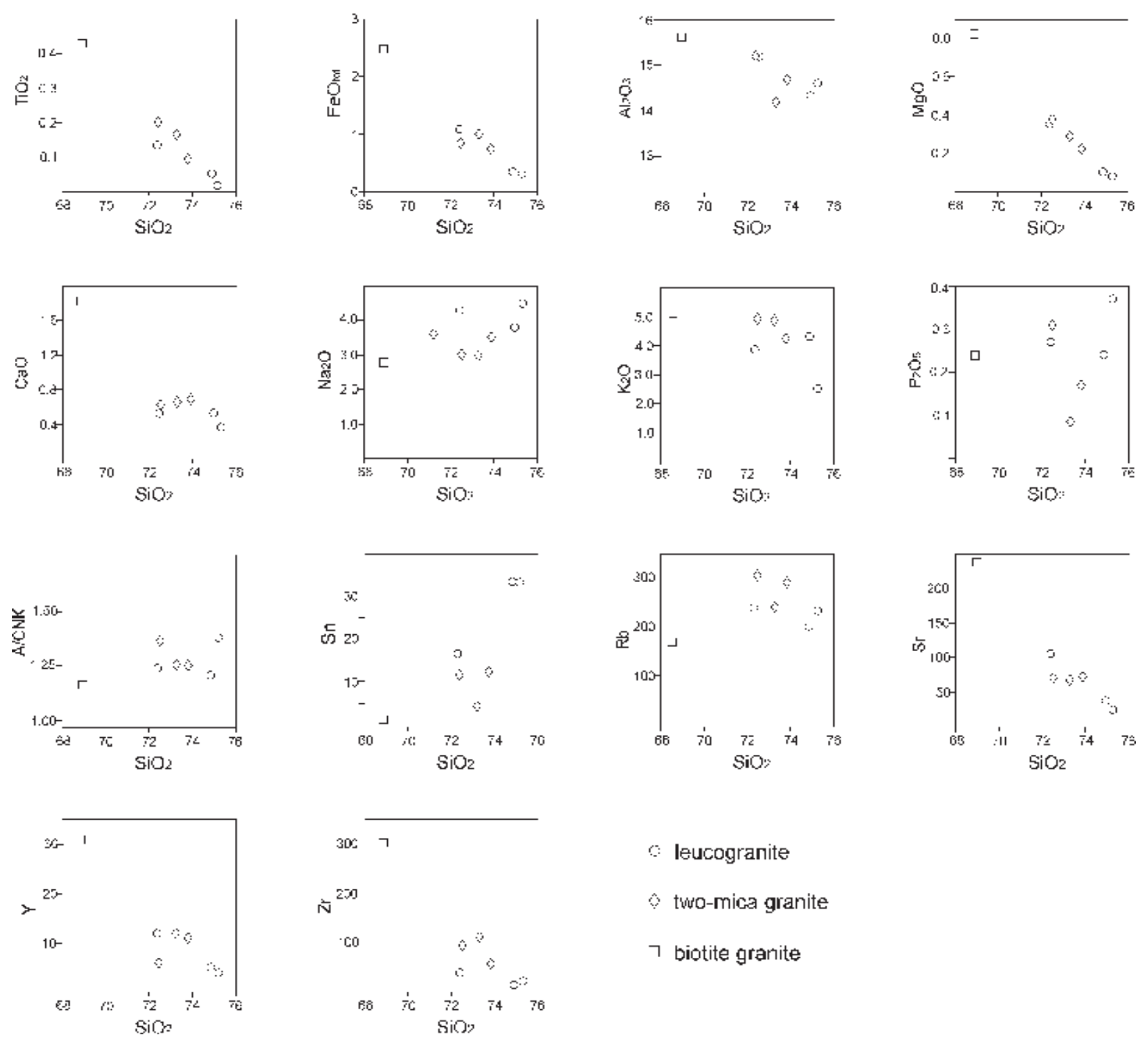

Fig. 6 Major and trace element plots vs. $\mathrm{SiO}_{2}$, and $\mathrm{A} / \mathrm{CNK}$ vs. $\mathrm{SiO}_{2}$ for leucogranite samples. Two-mica and biotite granite samples of the Vydra Pluton are plotted for comparison.

ages were determined in two samples: granite (sample 51) and orthogneiss (sample G30a), see Fig 2.

Sample 51: biotite granite from the central part of the Vydra Pluton, monazite crystals are scarce and small, about 5 microns across.

Sample G30a: biotite orthogneiss, medium-grained foliated pre-Variscan granite, most probably of Lower Ordovician age (following recent dating of similar rocks from the Bavarian side, Teipel et al. 2004). The orthogneiss is cut by the leucogranite dyke (sample G30), which is clearly younger, discordant to regional foliation (Fig. 3a). Abundant monazite forms elongated crystals oriented parallel to foliation, mostly grown in the cleavage of biotite flakes. The mode of monazite occurrence provides an evidence for its secondary metamorphic origin.

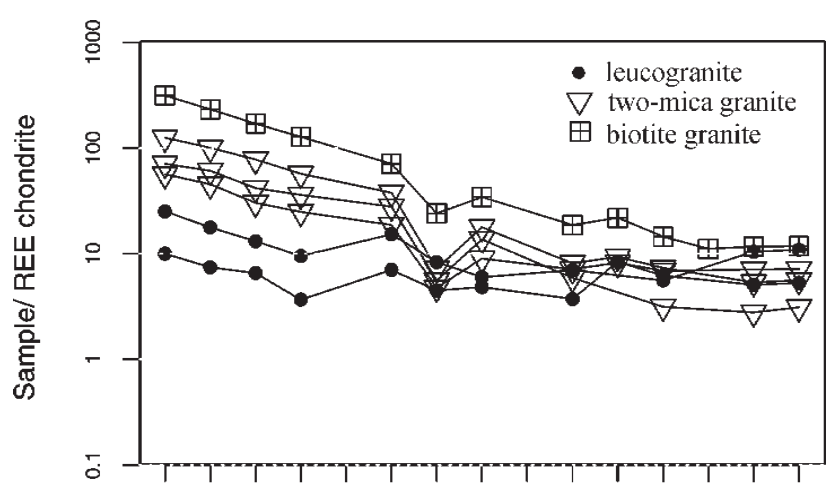

La Ce Pr Na Sm Eu Gd Tb Dy Ho Er Tm Yb Lu

Fig. 7 Chondrite-normalized patterns of REE in leucogranite, marginal two-mica granite and biotite granite samples form the Vydra Pluton. Abundances are in ppm, normalized by chondrite values (Boynton 1984). 
Both samples yielded Variscan, within the error identical ages: sample 51: $327 \pm 35 \mathrm{Ma}$ (5 measurements); sample G30a: $326.6 \pm 6.9$ Ma (15 measurements) (Fig. 8.) The large error in the case of the former sample is caused by scarcity of monazite crystals in the studied rock, resulting in small number of measurements.

\section{Discussion and Conclusions}

Leucogranite dyke swarm occurs in metamorphic country rocks at the eastern periphery of the Vydra Pluton, approximately following the line (from the SE to NW) Nové Hutě - Zlatá Studna - Hut'ská Hora (Figs 1, 2). The shape of the Vydra Pluton, including its hidden part, is well documented by isolated granite bodies mapped in

Table 8 Chemical composition of monazite (biotite granite) and zircon (leucogranite).

\begin{tabular}{|c|c|c|c|c|c|}
\hline \multicolumn{4}{|c|}{51 - biotite granite - monazite } & \multicolumn{2}{|c|}{ G66 zircon* } \\
\hline $\mathrm{P}_{2} \mathrm{O}_{5}$ & 30.73 & 30.32 & 30.76 & $\mathrm{SiO}_{2}$ & 24.27 \\
\hline $\mathrm{La}_{2} \mathrm{O}_{3}$ & 15.01 & 13.64 & 9.25 & $\mathrm{ZrO}_{2}$ & 46.18 \\
\hline $\mathrm{Ce}_{2} \mathrm{O}_{3}$ & 30.26 & 28.46 & 25.01 & $\mathrm{Al}_{2} \mathrm{O}_{3}$ & 0.10 \\
\hline $\mathbf{U O}_{2}$ & 0.12 & 0.21 & 0.40 & $\mathrm{HfO}_{2}$ & 1.59 \\
\hline $\mathrm{SiO}_{2}$ & 0.17 & 0.45 & 0.41 & $\mathbf{P}_{2} \mathbf{O}_{5}$ & 6.56 \\
\hline $\mathbf{P b O}$ & 0.05 & 0.10 & 0.13 & $\mathrm{CaO}$ & 0.39 \\
\hline $\mathrm{Y}_{2} \mathrm{O}_{3}$ & 1.61 & 1.13 & 2.24 & $\mathrm{ThO}_{2}$ & 0.00 \\
\hline $\mathrm{Pr}_{2} \mathrm{O}_{3}$ & 3.09 & 3.17 & 3.10 & $\mathbf{U O}_{2}$ & 6.79 \\
\hline $\mathrm{Nd}_{2} \mathrm{O}_{3}$ & 11.72 & 11.16 & 12.14 & $\mathbf{Y}_{2} \mathbf{O}_{3}$ & 6.63 \\
\hline $\mathrm{Gd}_{2} \mathrm{O}_{3}$ & 0.98 & 1.04 & 2.59 & MnO & 0.10 \\
\hline $\mathrm{Sm}_{2} \mathrm{O}_{3}$ & 1.77 & 2.01 & 3.46 & $\mathrm{FeO}$ & 1.08 \\
\hline $\mathrm{ThO}_{2}$ & 3.02 & 6.43 & 8.31 & $\mathbf{F}$ & 0.00 \\
\hline $\mathrm{CaO}$ & 0.71 & 1.13 & 1.62 & $\mathrm{WO}_{3}$ & 0.74 \\
\hline $\mathrm{Dy}_{2} \mathrm{O}_{3}$ & 0.48 & 0.36 & 0.84 & $\mathrm{Yb}_{2} \mathrm{O}_{3}$ & 1.23 \\
\hline $\mathrm{Er}_{2} \mathrm{O}_{3}$ & 0.20 & 0.03 & 0.13 & $\mathrm{Sc}_{2} \mathrm{O}_{3}$ & 0.21 \\
\hline Total & 99.92 & 99.62 & 100.41 & Total & 95.88 \\
\hline
\end{tabular}

*La, Ce, Ti - below detection limit

a

Biotite granite: sample 51

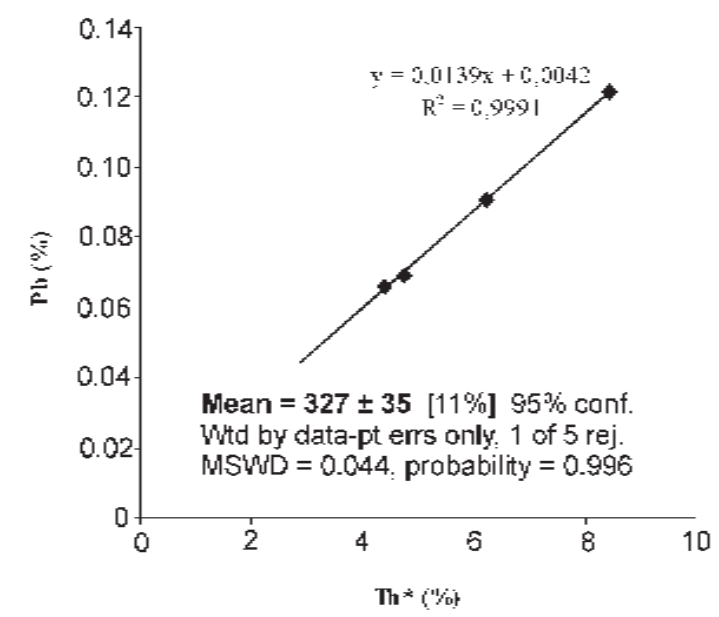

the vicinity of Horská Kvilda and Filipova Hut' (Žáček 2005) and supported by Linsser indication of density boundary at $-1000 \mathrm{~m}$, which is parallel with the leucogranite dyke swarm. The leucogranite represents fractionated peraluminous S-type granite influenced by late- and/ or post-magmatic boron-rich fluids. The amount of tourmaline in leucogranite varies between $0-5$ vol. \%. The strong enrichment in B and P presumably resulted in lowering magma viscosity (Dingwell et al. 1993, Johannes - Holtz 1996), enabling the emplacement of thin, dmsized leucogranite dykes (compare Figs 5-7, Table 2).

Potassium feldspar is the main host of phosphorus in the dyke leucogranite, whereas the $\mathrm{P}$ concentration in associated albite $\left(\mathrm{An}_{0-1}\right)$ remains surprisingly low: $\mathrm{P}_{2} \mathrm{O}_{5}$ WR $=0.24-0.37$ wt. $\%, \mathrm{P}_{2} \mathrm{O}_{5}{ }^{\mathrm{Kfs}}=0.65-0.95$ wt. $\%, \mathrm{P}_{2} \mathrm{O}_{5}{ }^{\mathrm{Ab}}=$ 0.0-0.17 wt. \%. In two-mica granite of the Vydra Pluton, both albite $\left(\mathrm{An}_{5-10}\right)$ and potassium feldspar are important phosphorus reservoirs, depending on $\mathrm{P}_{2} \mathrm{O}_{5}{ }^{\mathrm{WR}}$; sample 19: $\mathrm{P}_{2} \mathrm{O}_{5}{ }^{\mathrm{WR}}=0.17$ wt. $\%, \mathrm{P}_{2} \mathrm{O}_{5}{ }^{\mathrm{Kfs}}=0.22-0.54$ wt. $\%, \mathrm{P}_{2} \mathrm{O}_{5}{ }^{\mathrm{Ab}}=0.41-1.00$ wt. $\%$; sample 46: $\mathrm{P}_{2} \mathrm{O}_{5}{ }^{\mathrm{WR}}=$ 0.09 wt. $\%, \mathrm{P}_{2} \mathrm{O}_{5}{ }^{\mathrm{Kfs}}=0.0-0.24$ wt. $\%, \mathrm{P}_{2} \mathrm{O}_{5}{ }^{\mathrm{Ab}}=0.0-0.22$ wt. \%. In addition, both mentioned types contain also accessory apatite, which is late in the crystall-ization sequence. Feldspars of biotite granite contain low concentrations of phosphorus $\left(\mathrm{P}_{2} \mathrm{O}_{5}{ }^{\mathrm{WR}}=0.24\right.$ wt. $\%, \mathrm{P}_{2} \mathrm{O}_{5}{ }^{\mathrm{Kfs}}=$ $0.03-0.09$ wt. $\%, \mathrm{P}_{2} \mathrm{O}_{5}{ }^{\mathrm{Pl}}=0.07-0.12$ wt. $\%$ and the main host of phosphorus is apatite (see Table 4). As documented above, biotite and two-mica granite show about equal concentrations of phosphorus both in plagioclase $\left(\mathrm{An}_{21-22}\right)$ and in potassium feldspar or a slight preference of phosphorus in albite. In contrast, leucogranites are characterized by strong enrichment of phosphorus in potassium feldspar. This dichotomy may be connected with a late/ post-magmatic alteration, during which phosphorus is easily released from plagioclase lattice (London 1992, Breiter 1999, Breiter et al. 2002). Major- and minor- el-

b

\section{Orthogneiss, sample G30a}

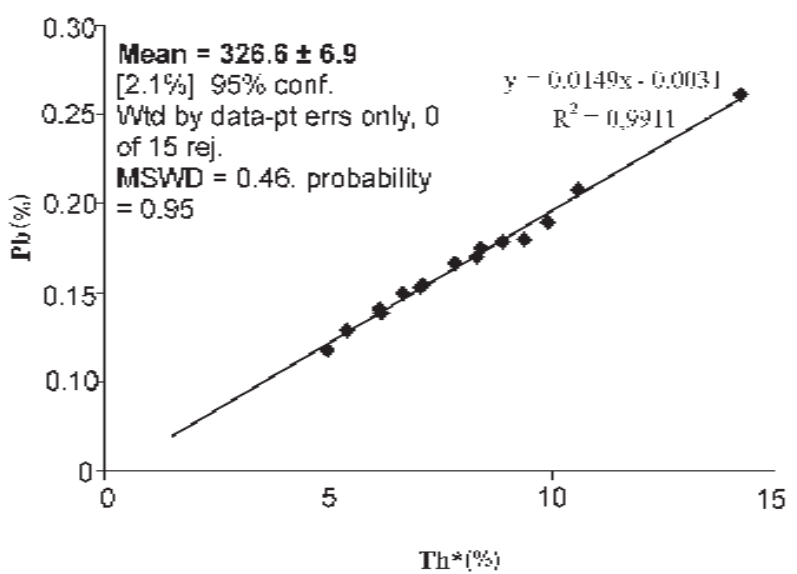

Fig. 8 A and B - Th* vs. Pb isochron plot for biotite granite (sample 51) from the central part of the Vydra Pluton (A) and for secondary metamorphic monazite from orthogneiss sample G30a (B), which is a host rock to the leucogranite sample G30. 
ement characteristics, and common trends of the three granite types in the binary plots clearly show that the marginal two-mica granite of the Vydra Pluton is intermediate between the biotite granite and the leucogranite (see Figs 5-7). This relation can be seen as an evidence for a common magma source of the Vydra Pluton and the leucogranite dyke swarm.

The chemical data for aplitic leucogranites rimming the Vydra Pluton, especially similar REE patterns, high boron and high concentration of phosphorus in alkali feldspars, indicate similarities of these small dykes to orebearing albite - topaz - Li-mica granitic systems, for instance Homolka granite, Moldanubian Batholith (Frýda - Breiter 1995, Breiter - Scharbert 1995), Podlesí granite system, Krušné Hory and Beauvoir granite, France (Raimbault et al. 1995), and Hnilec granite, Slovakia (Broska et al. 2002). These rocks have been studied intensively during the last decade because alkali feldspars and not phosphates were found to be the main reservoirs of phosphorus in the rock (London 1992, Bea et al. 1992, London et al. 1993, Pichavant et al. 1992, Wolf et al. 1994, Raimbault et al. 1995, Frýda - Breiter 1995, Breiter 1998, Breiter - Scharbert 1998, Mysen et al. 1999, Breiter et al. 2005b). Similarity of these rocks is also documented by the presence of unique, P- U- Y-rich zircons, described recently by Breiter et al. (2005a) from Podlesí granite (Table 8). The leucogranites studied are also close to some dyke rocks; e.g. to Lásenice porphyries reported by Klečka - Vaňková (1988) or to alkali-feldspar granite porphyry dyke swarm reported from the vicinity of Milevsko, Central Bohemian Pluton (Vrána 1999). Small aplite - leucogranite dykes are locally very common in the broader area of the metamorphosed basement of the Šumava Mts. based on published and manuscript geological maps of the Czech Geological Survey (e.g. Babůrek et al. 2000), as well as several personal communications (e.g. A. Seifert, V. Štědrá, 2005). However, these rocks have been little studied so far.

Acknowledgement: The authors are grateful to S. Vrána and V. Janoušek from the Czech Geological Survey, Prague, for inspiring comments and critical reading of the manuscript.

Submitted February 15, 2006

\section{References}

Amli, R. - Griffin, W. L. (1975): Microprobe analysis of REE minerals using empirical correction factors. - Amer. Mineralogist, 60: 599-606.

Babůrek, J. - Fürich, V. - Goliáš, V. -Hanžl, P. - Kadlecová, R. - Lhotský, P. - Nekovařik, Č. - Nývlt, D. - Osterrothová, K. - Pertoldová, J. Strnad, L. - Šebesta, J. - Vlčková, L. (2000): Vysvětlivky k základní geologické mapě České republiky, list 22-332 Kašperské Hory, MS, Česká geologická služba. Praha.

Bea, F. -Fershtater, G. B. - Corretgé, L. G. (1992): The geochemistry of phosphorus in granite rocks and the effects of aluminium. - Lithos, 29: 43-56.

Boynton, W. V. (1984): Cosmochemistry of the rare earth elements: meteoritic studies. - In: Henderson, P. (ed.): Rare Earth Elements Geochemistry. Elsevier. Amsterdam.
Breiter, K. (1998): Geochemical evolution of P-rich granite suites: Evidence from Bohemian Massif. - Acta Univ. Carol., Geol., 42: 7-19.

- (1999): Phosphorus in alkali feldspars - possible constrains of granite genesis interpretation. - Eur. J. Mineral., 11, Beihefte $1 / 1999,42$.

- (2002): From explosive breccia to unidirectional solidification textures: magmatic evolution of a phosphorus- and fluorine-rich granite system (Podlesí, Krušné Hory Mts., Czech Republic. - Bull. Czech Geol. Surv., 77: 65-92. Praha.

Breiter, K. - Frýda, J. - Leichmann, J. (2002): Phosphorus and rubidium in alkali feldspars: case studies and possible genetic interpretation. Bull. Czech Geol. Surv., 77: 93-103. Praha.

Breiter, K. - Müller, A. - Leichmann, J. - Gabašová, A. (2005b): Textural and chemical evolution of a fractionated granitic system: the Podlesí stock, Czech Republic. - Lithos, 80: 323-345.

Breiter, K. - Scharbert, S. (1995): The Homolka magmatic centre: an example of late Variscan ore-bearing magmatism in the Southbohemian Batholith (southern Bohemia, northern Austria). - Jb. Geol. Bundesanst., 138: 9-25. Wien.

- (1998): Latest Intrusions of the Eisgarn Pluton (South Bohemia - Northern Waldviertel). - Jb. Geol. B.-A., 141, 25-37.

Breiter, K. - Škoda, R. - Förster, J. H. (2005a): Unusual zircon from fractionated peraluminous granite. -2 . sjezd České geologické společnosti, Slavonice, 19.-22. ř́ijna 2005, Abstracts, p.14. (in Czech)

Broska, I. - Kubiš, M. - Williams, C. T. - Konečný, P. (2002): The compositions of rock-forming minerals from the Gemeric granites (Hnilec area, Gemeric Superunit, Western Carpathians). - Bull. Czech Geol. Surv., 77: 147-155. Praha.

Cocherie, A. - Legendre, O. - Peucat, J. J. - Kouamelan, A. (1998): Geochronology of polygenetic monazites constrained by in situ electron microprobe Th-U-total $\mathrm{Pb}$ determination: implications for $\mathrm{Pb}$ behavior in monazite. - Geochimica et Cosmochimica Acta, 62: 2475-2497.

Dallmeyer, R. D. - Franke, W. - Weber, K. (eds.) (1995): Pre-Permian geology of Central and Eastern Europe. Berlin. Springer Verlag.

De La Roche, H. - Leterrier, J. - Grandclaude, P. - Marchal, M. (1980): A classification of volcanic and plutonic rocks using R1R2-diagram and major element analyses - its relationships with current nomenclature. - Chem. Geol., 29: 183-210.

Dingwell, D. B. - Knoche, R. - Webb, S. L. (1993): The effect of $\mathrm{P}_{2} \mathrm{O}_{5}$ on the viscosity of haplogranitic liquid. - Eur. J. Mineral., 5: 133-140.

Finger, F. -Roberts, M. P. - Haunschmidt, B. - Schermaier, A. - Schreyer, H. P. (1997): Variscan granitoids of central Europe: their typology, potential sources and tectonothermal relations. - Mineralogy and Petrology, 61: 67-96.

Förster, J. H. - Tischendorf, G. (1994): The western Erzgebirge-Vogtland granites: implication to the Hercynian magmatism in the Erzgebirge - Fichtelgebirge anticlinorium. - In: R. Seltmann, H. Kämpf, P. Möller (eds.): Metallogeny of collisional orogens. - Proceedings of the IAGOD Erzgebirge meeting, Geyer, June 1993: 35-48.

Frýda, J. - Breiter, K. (1995): Alkali feldspars as a main phosphorus reservoirs in rare metal granites: three examples from the Bohemia Massif (Czech Republic). - Terra Nova, 7: 315-320.

Gerdes, A. - Friedl, G. - Parrish, R. R. - Finger, F. (2003): High-resolution geochronology of Variscan granite emplacement - the South Bohemian Batholith. - J. Czech Geol. Soc., 48: 53-54.

Jenček, V. - Vajner, V. (1968): Stratigraphy and relations of the groups in the Bohemian part of Moldanubicum. - Krystalinikum, 6: 105-124.

Johannes, W. - Holtz, F. (1996): Petrogenesis and Experimental Petrology of Granitic Rocks. Berlin. Springer.

Klečka, M. - Matějka, D. (1996): Moldanubian Batholith - an example of the evolution of the Late Palaeozoic granitoid magmatism in the Moldanubian Zone, Bohemian Massif(Central Europe). - In: Srivastava, R. K. - Chandra, R. (eds) : Magmatism in relation to diverse tectonic settings. Oxford \& IBH Publishing Co., New Delhi: 353-373.

Klečka, M. - Vaňková, V. (1988): Geochemistry of felsic dykes from the vicinity of Lásenice near Jindřichův Hradec (South Bohemia) and their relation to Sn-W mineralization. - Čas. Mineral. Geol., 33: 225-250.

Liew, T. C. - Finger, F. - Höck, V. (1989): The Moldanubian granitoid plutons in Austria: chemical and isotopic studies bearing on their environmental setting. - Chem. Geol., 76: 41-45. 
London, D. (1992): Phosphorus in S-type magmas: the $\mathrm{P}_{2} \mathrm{O}_{5}$ content of feldspars from peraluminous granites, pegmatites and rhyolites. Amer. Mineralogist, 77: 126-145.

London, D. - Morgan, G. B. - Babb, H. A. - Loomis, J. L. (1993): Behavior and effects of phosphorus in the system $\mathrm{Na}_{2} \mathrm{O}-\mathrm{K}_{2} \mathrm{O}-\mathrm{Al}_{2} \mathrm{O}_{3}-\mathrm{SiO}_{2}-\mathrm{P}_{2} \mathrm{O}_{5}$ $\mathrm{H}_{2} \mathrm{O}$ at $200 \mathrm{MPa}\left(\mathrm{H}_{2} \mathrm{O}\right)$. - Contrib. Mineral. Petrol., 113: 450-465.

Ludwig, K. R. (2003): Isoplot 3.00 - A Geochronological Toolkit for Microsoft Excel. Berkeley Geochronology Center Special Publication No. 4.

Matějka, D. - Janoušek, V. (1998): Whole-rock geochemistry and petrogenesis of granites from the northern part of the Moldanubian Batholith (Czech Republic). - Acta Univ. Carol, Geol., 42: 73-79.

Montel, J.-M., Veschambre, M. - Nicollet, C. (1993): Datation de la monazite a la microsonde electronique. - C. R. Acad. Sci. Paris. 318 II: 1489-1495.

Mysen, B. O. - Holtz, F. - Pichavant, M. - Beny, J. M. - Montel, J. M. Holtz, F. (1999): The effect of temperature and bulk composition on the solution mechanism of phosphorus in peraluminous haplogranitic magma. - Amer. Mineralogist, 84: 1336-1345.

Pichavant, M. - Montel, J. M. - Richard, L. R. (1992): Apatite solubility in peraluminous liquids: experimental data and extension of the HarrisonWatson model. - Geochim. Cosmochim. Acta, 56: 3855-3861.

Pouchou, J. L. - Pichoir, F. (1984): A new model for quantitative analysis: Part I. Application to the analysis of homogeneous samples. - La Recherche Aerospatiale, 3: 13-38.

- (1985): ,PAP‘ Xy(rz) procedure for improved quantitative microanalysis, p. 104-106. Microbeam analysis, San Francisco Press, San Francisco.

Raimbault, L. - Cuney, M. - Azencott, C. - Duthou, J. L. - Joron, J. L. (1995): Geochemical evidence for a multistage magmatic genesis of
Ta-Sn-Li mineralization in the granite at Beauvoir, French Massif Central. - Econ. Geol., 90: 548-576.

Škoda, S. - Pálenský, P. (2005): New granite body find in surroundings of Zdíkov, Sumava Mts. - Zpr. Geol. Výzk. v r. 2004: 73-75. Praha. (in Czech)

Teipel, U. - Eichhorn, R. - Loth, G. - Rohrmüller, J. - Höll, R. - Kennedy, A. (2004): U-Pb SHRIMP and Nd isotopic data from the western Bohemian Massif (Bayerischer Wald, Germany): Implications for Upper Vendian and Lower Ordovician magmatism. - Int. J. Earth Sci. (Geol. Rundsch.), 93: 782-801.

Vellmer, C. - Wedepohl, K. H. (1994): Geochemical characterization and origin of granitoids from the South Bohemian Batholith in lower Austria. - Contrib. Mineral. Petrol., 118: 13-32.

Vrána, S. (1999): Dyke swarm of highly evolved felsitic granite porphyry near Milevsko, Central Bohemian Pluton. - Bull. Czech Geol. Surv., 74: 67-74. Praha.

Wolf, M. B. - London, D. (1994): Apatite dissolution into peraluminous haplogranitic melts; an experimental study of solubilities and mechanisms. - Geochim. Cosmochim. Acta, 58: 4127-4146.

Žáček, $V$. (2005): Geological map of the Czech Republic 1:25 000, sheet 22-334 Kvilda - MS, Czech Geological Survey. Praha.

Žáček, V. - Břizová, E. - Havlíček, P. - Lhotský, P. - Krupička, J. Lysenko, V.-Mrnková, J. - Nováková, D. - Skácelová, D. - Šebesta, J. - Šrámek, J. - Verner, K. - Žák, J. (2005): Explanatory booklet to the geological map of the Czech Republic 1:25 000, sheet 22-334 Kvilda. - MS, Czech Geological Survey. Praha.

Žáček, V. - Vrána, S. (1999): Tourmaline of tourmalinites and quartz secretions from the Kaplice Unit (Southern Bohemia) - Bull. Mineral. - petrolog. Odd. Nár. Muz., 7: 233-235. Praha.(in Czech).

\section{Appendix: location of the samples}

\section{Leucogranite dyke swarm}

G21 - blocks $50-100 \mathrm{~cm}$ in size, $1 \mathrm{~km}$ south of České Chalupy, directly by the road.

G30, G30a - blocks 100-150 cm in size, $300 \mathrm{~m} \mathrm{NW}$ from the Churáňov hill (1119 m), at forest road. Both orthogneiss (G30a) and leucogranite (G30) occur there. Leucogranite dykes are discordant to the foliation in orthogneiss.

G66 - block $1 \mathrm{~m}$ across, $500 \mathrm{~m}$ NW of the U Tř́ Jedlí hill, at the forest road, $2.5 \mathrm{~km}$ NE of Horská Kvilda.

\section{The Vydra Pluton}

19 - two-mica granite, blocks 1-4 m in size at the forest edge, $250 \mathrm{~m}$ SSE of Vydří Most, Horská Kvilda.

45 - two-mica granite, artificial exposure at the road $250 \mathrm{~m}$ NW of Dolní Otýgl.

46 - two-mica granite, big natural outcrop "Hrádky", 2 km N of Rokyta.

51 - biotite granite, natural outcrop in the forest, $500 \mathrm{~m} \mathrm{NW}$ of Rokyta.

188 - quartz-tourmaline nodule $10 \mathrm{~cm}$ across, enclosed in migmatite, directly at the old forest path "Zlatá stezka", $450 \mathrm{~m}$ north of Hut'ská Hora.

\section{Žilný roj diferencovaného turmalinického leukogranitu a jeho vztah k masivku Vydry (moldanubický pluton, Šumava)}

Během geologického mapování listu 22-334 Kvilda v letech 2003-2005, bylo při východním okraji masivku Vydry (peraluminický granit S-typu, který patři k západní větvi moldanubického plutonu) zjištěno velké množství drobných žil a tělísek aplitického leukogranitu, které diskordantně pronikají okolními metamorfity. Tyto žíly o mocnosti $\sim 20 \mathrm{~cm}$ až asi $5 \mathrm{~m}$ lemují pluton v určité vzdálenosti, obvykle $2-4 \mathrm{~km}$ a jsou koncentrovány v pásmu o délce nejméně 12 km a šiřce 1-3 (5) km; nebyly však zjištěny k plutonu bliže, ani v plutonu samém. Leukogranity se skládají z křemene, albitu, draselného živce a muskovitu, většinou přistupuje také černý turmalín, hořečnatý X-vakantní skoryl (až $5 \mathrm{obj}$. \%) a biotit, akcesorické jsou apatit a U-Y-P-bohatý zirkon. Hornina se vyznačuje nízkými koncentracemi $\mathrm{Ca}$ a Ti, má nízkou hořečnatost $(\mathrm{mg})$, je peraluminická, $\mathrm{A} / \mathrm{CNK}=1,21-1,36$, poměr $\mathrm{K}_{2} \mathrm{O} / \mathrm{Na}_{2} \mathrm{O}$ vykazuje střední hodnoty: $0,53-1,14$. Větší část fosforu v hornině je vázána ve formě sekundárního apatitu, jeho významná část je však vázána zejména v draselném živci $\left(0,65-0,95 \mathrm{hm}\right.$. \% $\left.\mathrm{P}_{2} \mathrm{O}_{5}\right)$, zatímco v albitu jsou koncentrace $\mathrm{P}_{2} \mathrm{O}_{5}$ nesrovnatelně nižší a to jen $0,01-0,17 \mathrm{hm}$. \%. Anomální distribuce fosforu v živcích je interpretována jako důsledek pozdně magmatické či post magmatické alterace, která vedla k přednostnímu uvolnění fosforu z mřǐžky albitu a ke vzniku sekundárního apatitu. Srovnáme-li chemické složení leukogranitů s granity masivku Vydry, leukogranity jsou relativně bohatší $\mathrm{SiO}_{2}$, $\mathrm{Na}_{2} \mathrm{O}$ a Rb (200-240 ppm), silně pak obohacené o Sn (17-34 ppm) a bór (hojný turmalín); naproti tomu jsou to horniny středně až silně ochuzené o $\mathrm{V}$, $\mathrm{Cr}, \mathrm{Ni}$, Sr, Ba a LREE (S REE 7-40 ppm). Poměr K/Rb se pohybuje v rozmezí 88-133, poměr Rb/Sr pak 2,3-10,2. Další charakteristickou vlastností leukogranitů je jejich poměrně nízká radioaktivita, zejména pak nízké koncentrace Th (většinou 1,2-3 ppm), a velmi nízký poměr Th/U, obvykle pod 0,4. Nové U-Th datování na monazitu potvrdilo variské stárí (326,6 $\pm 6,9$ MA) metamorfózy okolního krystalinika. 